Int. J. Electrochem. Sci., 16 (2021) Article ID: 210736

International Journal of

ELECTROCHEMICAL

SCIENCE

www.electrochemsci.org

Short Communication

\title{
Poly-ortho-phenylenediamine Modified Pt/Ir Microelectrode as Impedimetric Biosensor
}

\author{
Norazreen Zakaria, Yusairie Mohd, Lim Ying Chin, Muhammad Noor Jalil and Zainiharyati Mohd \\ Zain $^{*}$
}

Electrochemical Material and Sensor (EMaS) Research Group, Faculty of Applied Sciences, Universiti Teknologi MARA, Shah Alam, 40450, Selangor, Malaysia.

"E-mail: Zainihar@uitm.edu.my

doi: $10.20964 / 2021.07 .66$

Received: 1 April 2021 / Accepted: 8 May 2021 / Published: 31 May 2021

\begin{abstract}
A low impedance between the microelectrode surface and brain biological tissue interface is important for a good signal quality during immunosensor recording to prevent tissue damage during electrical stimulation. The incorporation of a conducting polymer on a microelectrode surface with an internal diameter of $50 \mu \mathrm{m}$ can significantly reduce the electrode-electrolyte (brain lysate) impedance. An impedimetric immunosensor assay was developed by exploiting the Poly ortho-phenylenediamine (PoPD) conducting properties and has been electrodeposited on the Pt/Ir microelectrode surface. The modified PoPD-Pt/Ir was further biofunctionalised with glutaraldehyde (GA) that act as a crosslinker to mouse monoclonal $\mathrm{A} \beta$ antibody (mA $\beta \mathrm{ab}$ ) immobilisation on PoPD-Pt/Ir. An immunosensor is a simpler and faster method for real-time monitoring of amyloid beta $(\mathrm{A} \beta 40)$ based on antigen-antibody binding properties compared to the microdialysis technique in a real-time neurochemical study. This Pt/Ir-PoPDGA- $\mathrm{mA} \beta \mathrm{ab}$ immunosensor was tested with a trace amount of $\mathrm{A} \beta 40$ in the brain tissue lysate sample. Nyquist plots revealed the specific binding of $\mathrm{mA} \beta \mathrm{ab}$-amyloid beta $(\mathrm{A} \beta 40)$ to the biofunctionalised PoPD modified microelectrode surface. Furthermore, proposed equivalent circuits were developed in conjunction with each stage of biofunctionalisation layers on modified Pt/Ir microelectrode to fit and interpret the circuit components that could further explain certain chemical processes and mechanisms of the immunosensor system such as the effect of the electrical component of PoPD film formed during fabrication and its physicochemical properties. The advantages of this needle-like immunosensor include the use of a minimal amount of protein immobilisation reagents with a highly sensitive, selective, and rapid detection technique.
\end{abstract}

Keywords: Electrochemical Impedance Spectroscopy, Equivalent circuit, Amyloid Beta, Immunosensor, Platinum microelectrode.

\section{FULL TEXT}


(C) 2021 The Authors. Published by ESG (www.electrochemsci.org). This article is an open access article distributed under the terms and conditions of the Creative Commons Attribution license (http://creativecommons.org/licenses/by/4.0/). 